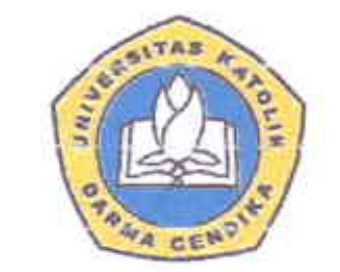

SAPIENTIA ET VIRTUS

durnat Berkala FH UKBC

Jl. Dr.lr. H. Soekarno 201 Surabaya | Tel (031) 5946482 | Fax (031) 5939625

http://ukdc.ac.id/jurnal/index.php/SEV, E-mail: fakultas.hukum@ukdc.ac.id

Hal : Penerimaan Naskah Pubiïkasi Jurnai

Kepada Yth.

JUAN IVANDER CHIRISTIAN

Terima kasih teian mengirimikan anikei ïmiah untuk diterbitikan pada Jurnai Sapientia et virtus (ISSN 2355-343X) dengan judu!:

\title{
KEPASTIAN HUKUM MENGENAI JANGKA WAKTU SEBAGAI TERSANGKA DALAM PROSES PENYIDIKAN DI INDONESIA
}

B̈erdasarkan hasii review yang teiah diilakukan, artikeỉ tersebut dinyatakan DITEKìî̉ dan teiah dipublikasikan di Jurnal Sapientia et Virtus Volume 3, NIomor 2.

Kami akan mengirimkan edisi cetak dari jumal tersebut ke penulis. Artikel tersebut telah lebih dahulu tersedia secara daring (online) di: http:/ukdc.ac.id/jumalindex.php/SFV/article/view/253.

Demikian informasi ini disampaikan, dan atas perhatiannya diucapkan terima kasỉn.

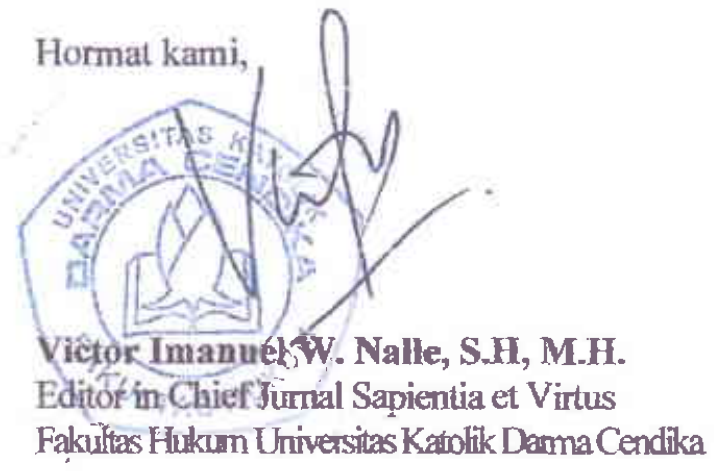




\title{
KEPASTIAN HUKUM MENGENAI JANGKA WAKTU SEBAGAI TERSANGKA DALAM PROSES PENYIDIKAN DI INDONESIA
}

\author{
Juan Ivander Christian
}

Juanivander40@gmail.com

Progam Studi Magister Ilmu Hukum Fakultas Hukum Universitas Surabaya

\begin{abstract}
Abstrak - Negara Indonesia adalah Negara Hukum sebagaimana telah diatur dalam ketentuan Pasal 1 ayat (3) Undang-undang Dasar Negara Republik Indonesia tahun 1945. Sistem pemerintahan maupun penegakan hukum harus dilakukan berdasarkan peraturan perundang-undangan, Undang-undang nomor 8 tahun 1981 tentang kitab hukum acara pidana (KUHAP) sebagai pedoman untuk penegakan hukum materiil. Tersangka mempunyai seperangkat hak yang telah diatur dalam KUHAP, berdasarkan ketentuan Pasal 50 ayat (1) KUHAP bahwa tersangka berhak segera mendapat pemeriksaan oleh penyidik dan selanjutnya dapat diajukan kepada penuntut umum. KUHAP sebagai pedoman untuk penegakan hukum materiil tidak mengatur mengenai jangka waktu penyidikan dan tidak mengatur mengenai perlindungan hukum yang dapat diberikan kepada tersangka yang perkaranya tidak dilimpahkan dalam proses penuntutan dan tidak diberikan surat perintah penghentian penyidikan sehingga tidak memberikan kepastian hukum. Di dalam beberapa hal yaitu UU Pengadilan HAM dan Peraturan Kepala Kepolisian Negara Republik Indonesia nomor 12 tahun 2009 tentang pengawasan dan pengendalian penanganan perkara pidana dilingkungan kepolisian Indonesia telah mengatur jangka waktu penyidikan. UU Pengadilan HAM tidak dapat diterapkan dalam semua tindak pidana di Indonesia melainkan hanya khusus dapat diterapkan dalam tindak pidana HAM berat, sedangkan peraturan kepala kepolisian negara republik Indonesia tidak mengatur secara jelas mengenai berapa lama dapat dilakukan perpanjangan waktu penyidikan dan peraturan tersebut diatas hanya berlaku dalam ruang lingkup kepolisian, sedangkan Pejabat Pegawai Negeri Sipil juga termasuk dalam penyidik. Serta peraturan tersebut tidak termasuk dalam hierarki peraturan perundang-undangan di Indonesia.
\end{abstract}

Kata Kunci : Jangka Waktu, Penyidikan, dan KUHAP 